\title{
RENOVATION OF 16TH CENTURY SALT HOUSE ROOF (LUBAŃ, LOWER SILESIA, POLAND) - CASE STUDY
}

\author{
KRZYSZTOF AŁYKOW ${ }^{1 *}$, MAGDALENA NAPIÓRKOWSKA-AŁYKOW \\ ${ }^{1}$ Team of Civil Engineers AŁYKOW \\ Kościuszki $1 / 4$ \\ 59-800 Lubań, Poland \\ e-mail: biuro@alykow.com, www.alykow.com (*corresponding author) \\ ${ }^{2}$ Team of Civil Engineers AŁYKOW \\ Kościuszki 1/ 4 \\ 59-800 Lubań, Poland \\ e-mail: audyty@alykow.com, www.alykow.com
}

Keywords: Historical Structure, Carpenter Construction, Masonry

\begin{abstract}
This article presents next step of the restoration works in the Salt House in Luban', Lower Silesia, Poland. The first stage of technical and conservatory problems which appeared during the restoration process was described in the article "Between conservators theory and modern construction's codes. Renovation of roof of 16th century Salt House in Luban', Lower Silesia, Poland", which was presented on 5th International Conference on Structural Health Assessment of Timber Structures, 25-27 September 2019, Guimarães, Portugal [1].
\end{abstract}

The Salt House in Lubań, Lower Silesia, Poland was erected between 1537 and 1539. This historic building is located between medieval defense walls, and it was used as a storage house for salt and grain until the end of the 18th century.

The technical documentation was prepared in 2016, which included 3-D scans of roof truss repair, as well as technical codes and restoration works. During the first phase of the works, the author of this article, who is also a Supervising Engineer, and an expert of the Ministry of Culture and National Heritage Republic of Poland, discovered a lot of discrepancies between the technical documentation and reality. The differences as well as the attempts to adjust restoration works and the technology of works were widely presented in an article at the SHATiS'19, Portugal.

The authors of this article want to show the problems that appeared during the continuation of renovation works and their solutions with reference to historic timber and masonry structures.

\section{INTRODUCTION}

The Salt House was built in the years 1537 to 1539, between two rows of defense walls which had been erected in the period before the Town of Lubań received the Magdeburg rights in 1220. It was used mainly as a storehouse for salt and grains [2]. The roof was 
initially thought to have been built at a later date; however, the discovery made by the authors of this article, supported by later studies, including a dendrochronological examination [3], proved that, except for the $25 \%$ of filler materials from the 19th century, the building had the original roofing from the time when it was erected.

\section{PHASE 1 AND 2 OF THE PROJECT}

The work, originally planned in accordance with the 2016 construction documentation, involved replacement of the entire roof covering, which was made from ceramic double lapped plain tiles, with new roof tiles, the reinforcement of the timber roof truss elements, and bracing the exterior walls at the points where cracks appeared [4].

However, in 2017, after launching the project, the Supervising Engineer found that there were large discrepancies between the way the listed building was described in the documentation and its actual condition. The scope of roofing work was changed after consulting the Jelenia Góra Provincial Historic Buildings Conservation Office, because it was discovered that the roof tiles and other roof covering components were ca. $75 \%$ original, so it was decided that they would need to be preserved and restored.

The details of the first two stages of the project implementation, including conservation of the original roof covering with roof tiles (ca. $50 \%$ of the roof surface in situ), and the rehabilitation of the timber roof truss components, were described in detail in section [1]. Some non-typical solutions were adopted, with the objective to reconcile the theory of building conservation construction products

The decision to save the structure of the original tinber roof tuss y a n
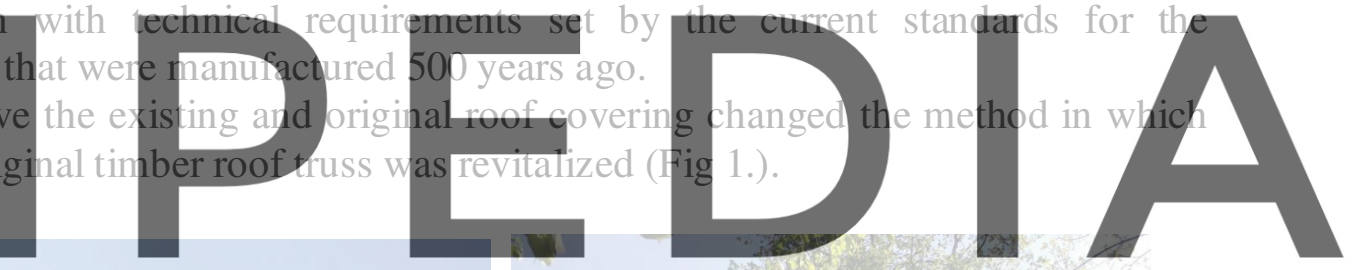

Register for free at https//www.scipedia.com to download the version without the watermark
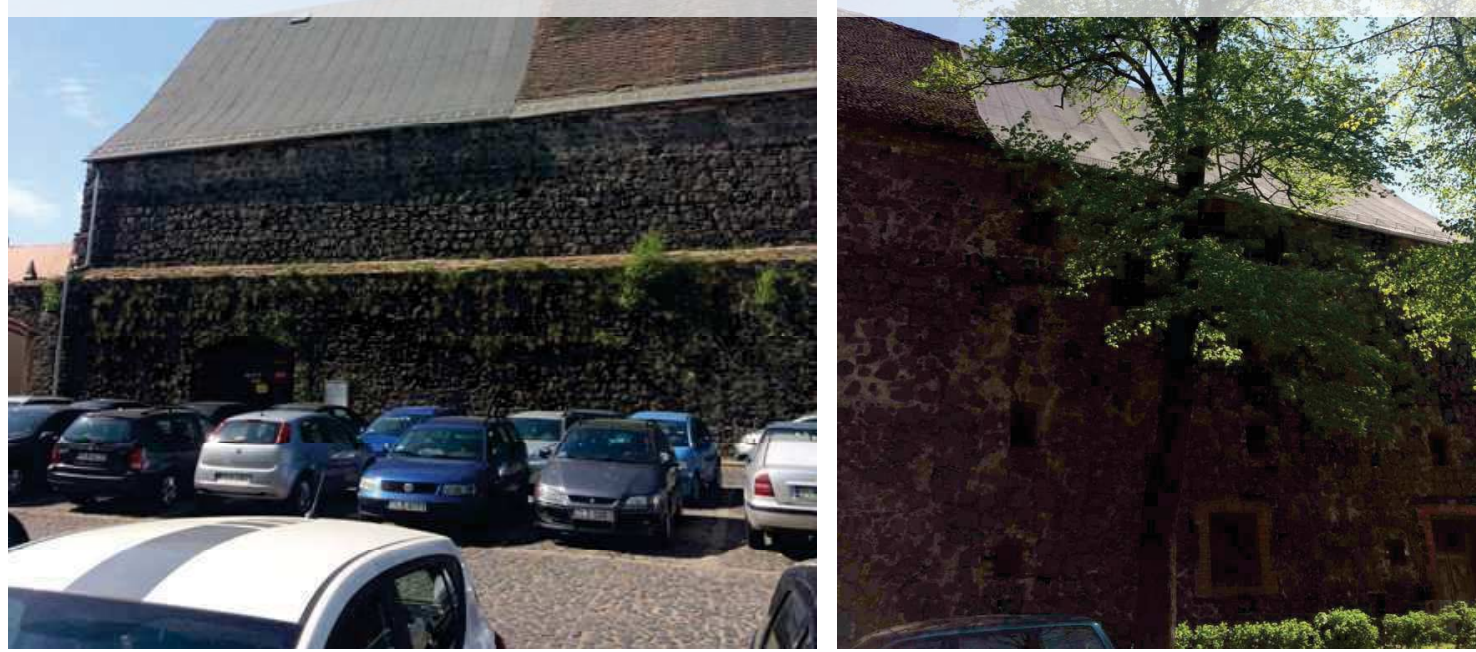

Figure 1: Temporary security after phase 1 and 2 


\section{PHASE 3 OF THE PROJECT}

Because of the fact that, prior to launching the project, the historical timber roof truss and wall structure were wrongly identified by construction designers during the preparation stage of the construction documentation, some of the technical solutions for the rehabilitation of those elements were erroneously adopted [5].

As a result of the examination carried out by the Supervising Engineer, who pointed out the right way to technically protect and revitalize the historical timber roof truss and wall structure, which happened during the work carried out in the years 2017 to 2019, both the erroneous identification and the conclusions that followed had to be modified.

\subsection{Timber Roof Truss Structure}

When it comes to the analysis of the timber roof truss, what was not considered in the construction documentation was the fact that it interacted with the trusses of three wooden beam floors located below the attic, including their earlier alterations and reinforcement.

The alterations, which were made while the building was in use, resulted from the need to provide stability of the roof trusses which rested against the upper part of the exterior walls and the end points of the tie beams, placed in the wall pockets, rotted and became partially truncated. They involved building in, at various points of time, at all floor levels, three or five rows of posts spaced in such a way as to match the tie beams, including plates and caps, which ran parallel to the central axis of the building (Fig.2, Fig. 3). This caused a significant
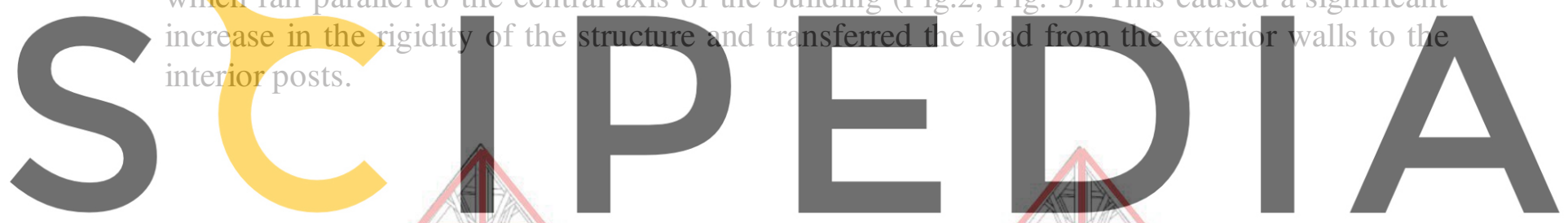

Register for free at https//www.scipedia.com to download the version without the watermark

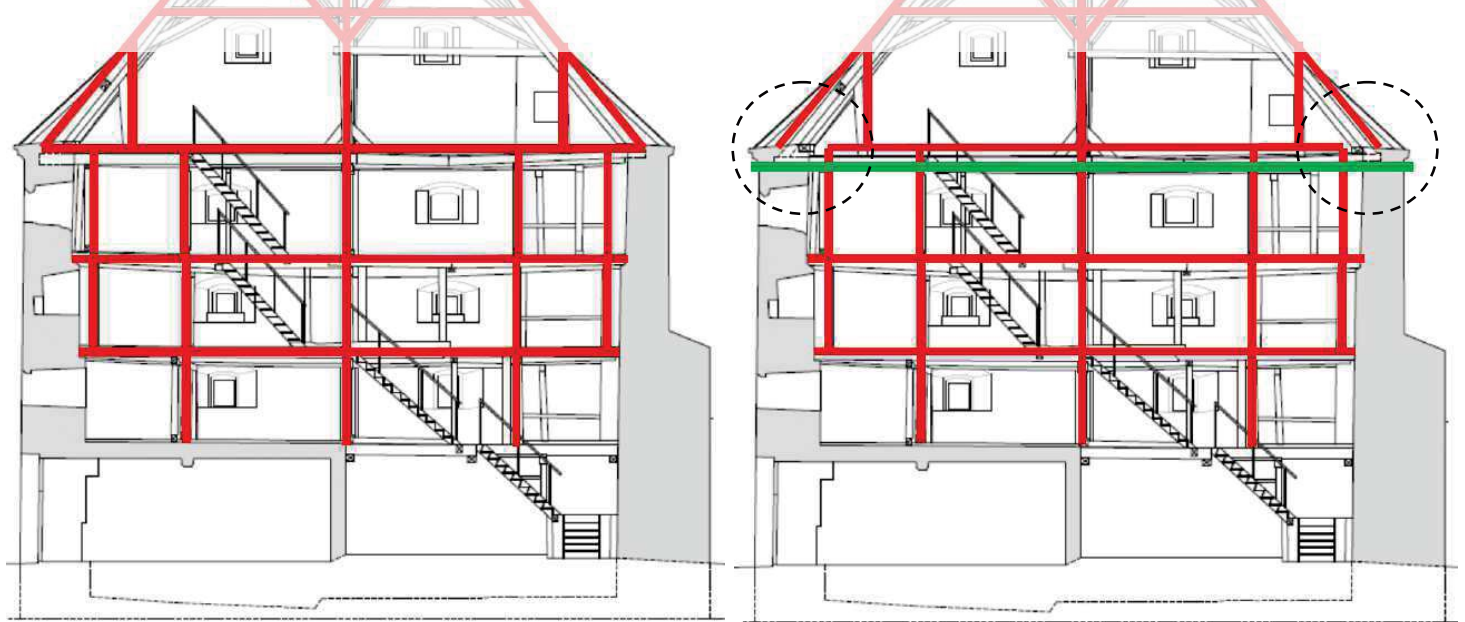

Figure 2: Cross section - original static scheme (left) and after change of its work (right); carpenter construction scheme - red, added steel tie rods - green, dashed circle - separation area 


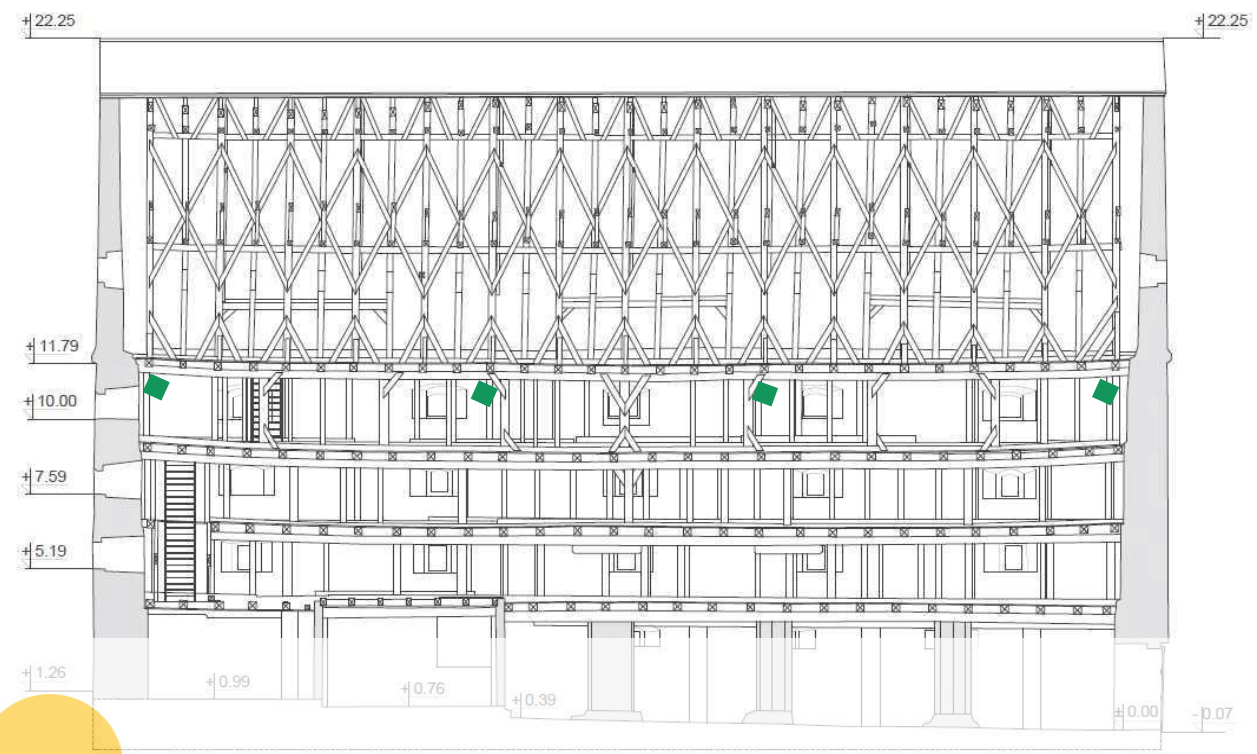

Figure 3: Longitudinal section; added steel tie rods - green

What was originally a king post truss, including two collar beams with every fourth main coupe with sloping rafters and struts, did no longer work as it was originally designed to do. Consequently, the tie heams acted as ordinary ceiling joists and the unbalanced horizontal loads were transferred by rafters directly to the upper part of the cxterior walls. Th
caused damage to the walls in the way which, paradoxically, made it easier to ex
structure and changes that had taken place. Contrary to what was assumed in the con
documentation, it proved impossible to retain the original, traditional way fo join in with rafters because the tie beans' endpoints as compared to their original length. That is why the Supervising Engineer made a decision to

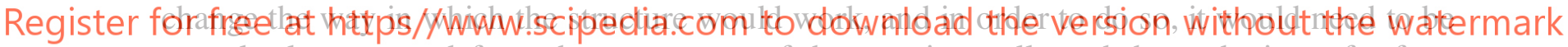
completely separated from the upper part of the exterior walls and the endpoints of rafters (Fig. 2 - red line, dashed circle - separation area) and false rafters would have to be supported in such a way as to enable their horizontal susceptibility (Fig. 4).

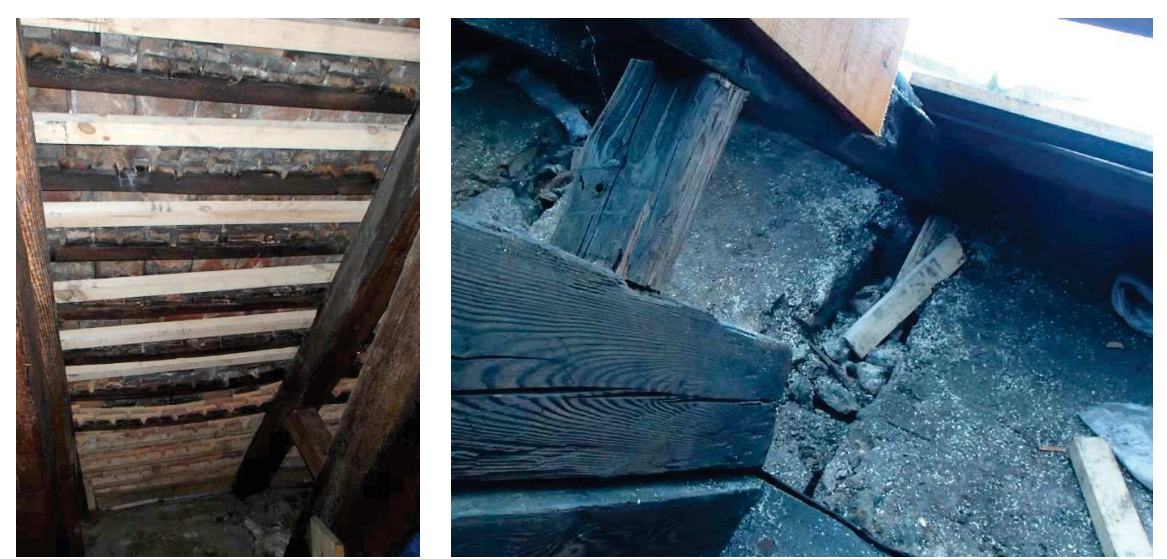

Figure 4: False rafters and reinforced timber roof truss components 
This made it possible to preserve the structure of the building - both with regards to timber roof truss components and, first and foremost, in terms of the original roof covering elements, including roof tiles, battens, shingles and lime mortar used for the installation of roof tiles, as well as clay mortar used as a sealant on the underside between the battens (Fig. 5) [6].
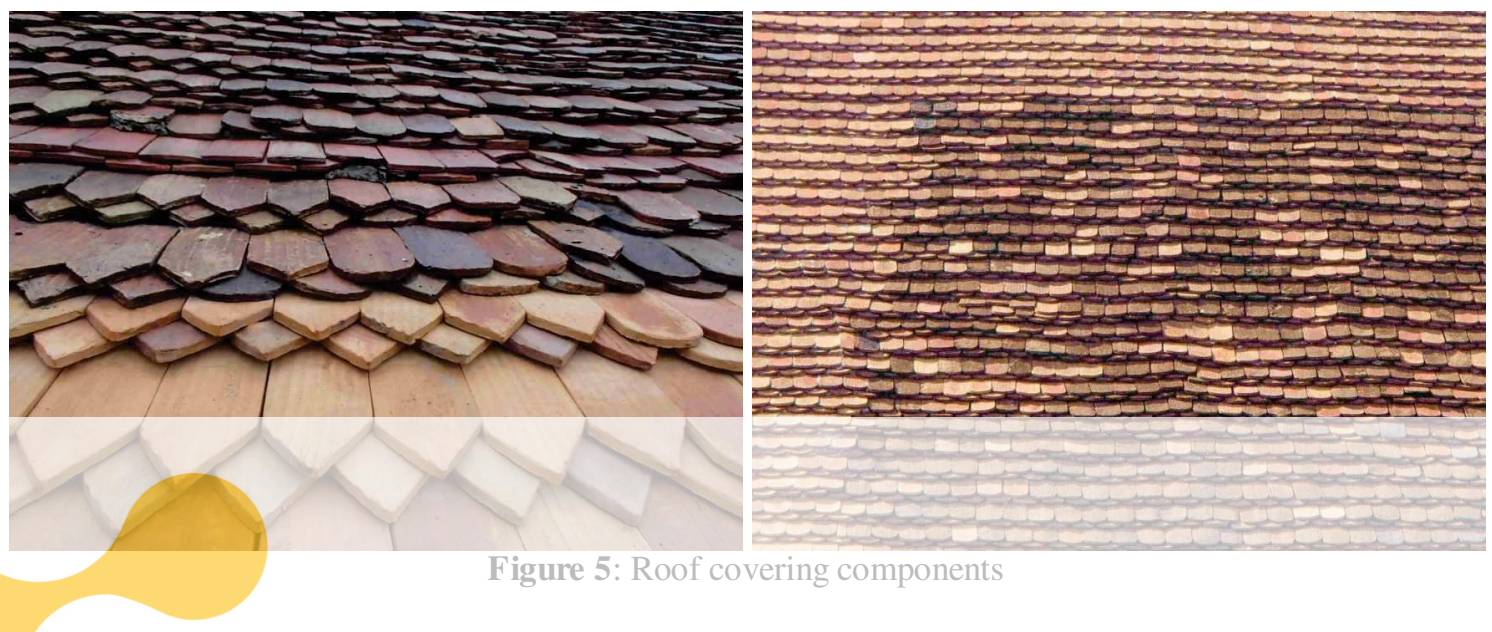

\subsection{Mas onry structure}

The changes that occurred within the original timber roof truss over 500 years damaged the
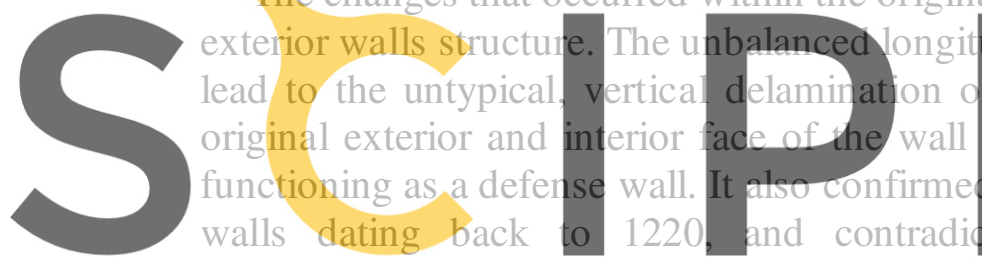

walls dating back

1220
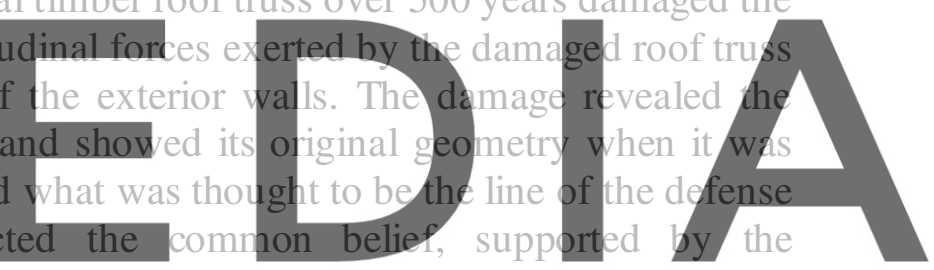

historiography, that the walls had been reconstructed at the time when the Salt House was

Register for free at https//www.scipedia,com to download the version without the watermark The Salt House was erected by building in its end walls between the existing defense walls,

without traditional masonry bonding in the corners of the building.

By having determined the way in which the walls got damaged and by learning about the cause of the damage, the Supervising Engineer was forced to change the stabilization method - contrary to what was shown in the construction documentation.

The global stability of the structure was achieved due to a considerable thickness of the defense walls - up to 3-meter thick, and the presence of the unbalanced horizontal reactions resulting from the compromised structural integrity of the timber roof truss also revealed the technique in which they were erected (Fig. 6).

Because of the lack of possibility to neutralize the horizontal reactions which were transferred onto the upper part of the walls, a set of tie rods was used in order to stabilize the upper part of the walls (Fig. 7, Fig. 2 right - green line) . 


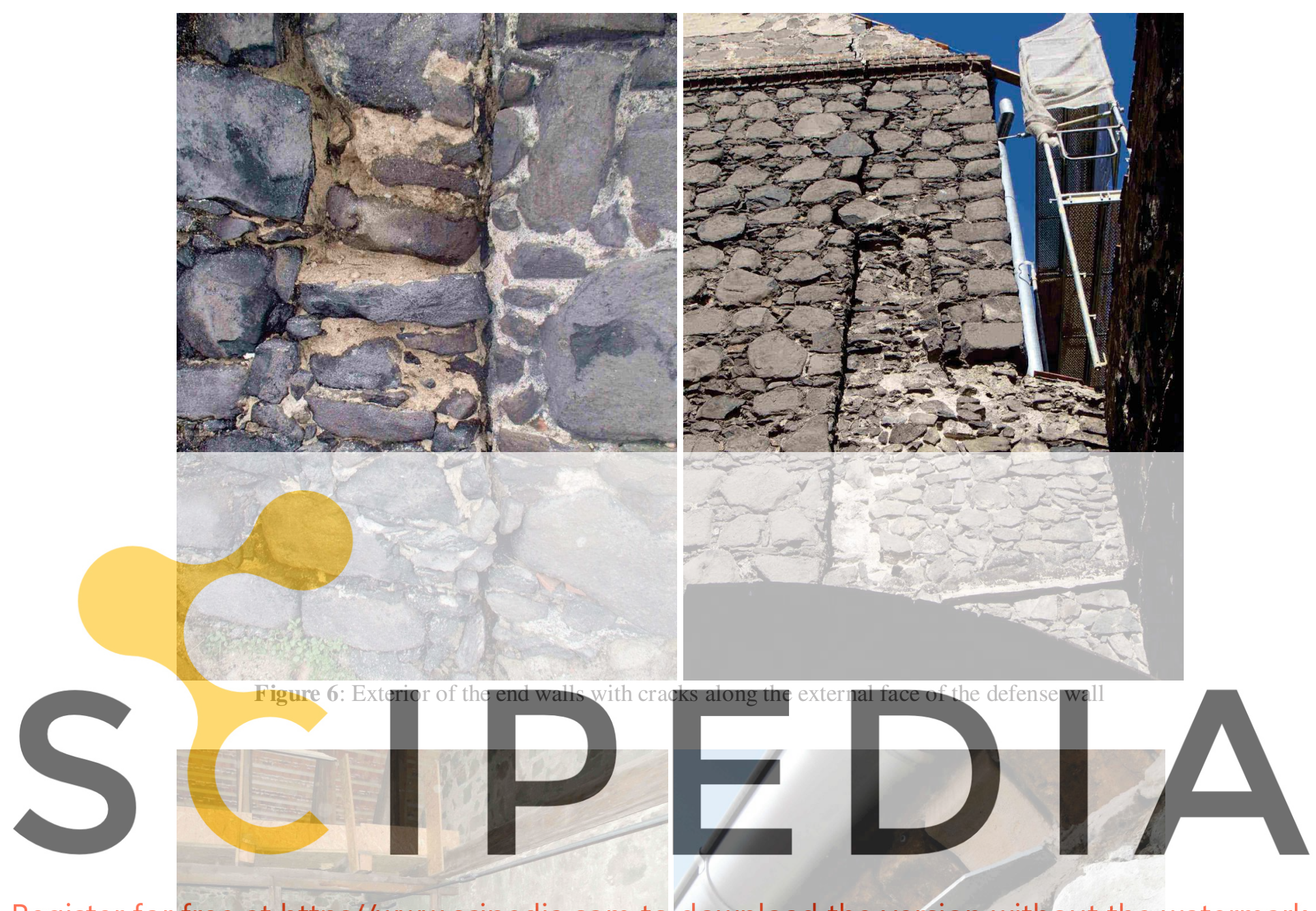

Register for free at https//www.scipedia.com to download the version without the watermark
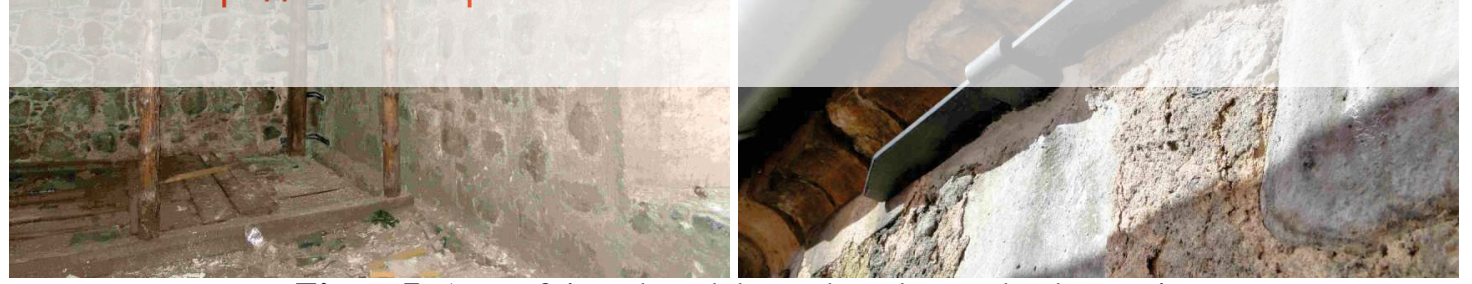

Figure 7: A set of tie rods and the anchor plate under the cornice

The reduction of the originally planned interference in the area where the roof trusses rested against the upper part of the walls also allowed to preserve the original layers of pugging which served as a protection of the upper part of the walls against the damaging impact of precipitation (Fig. 8). 

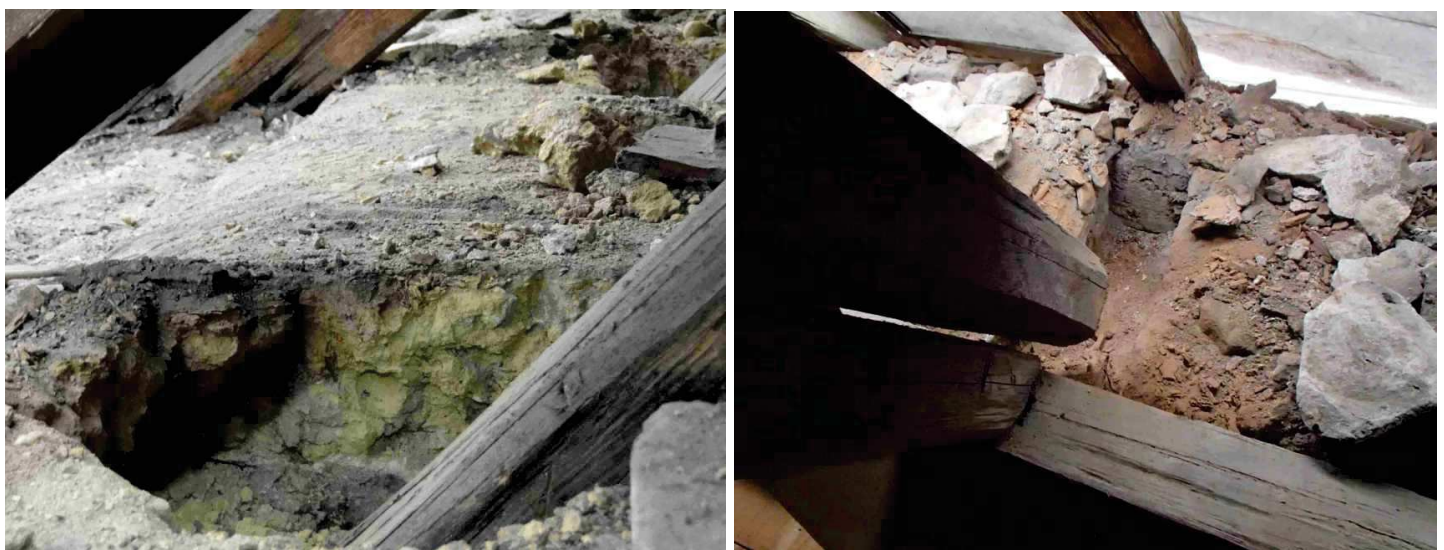

Figure 8: Pugging on the top part of the walls

\section{CONCLUSIONS}

The history of preparations and implementation of construction and conservation works involving the rehabilitation of the structure of the roof and walls of the Salt House in Luban strongly indicates that even though the current measurement methods are a great tool which can help examine a historical structure, they cannot substitute knowledge and experience of an individual who performs such type of works [7, 8].

In this case, the technical solutions proposed in the construction documentation of the

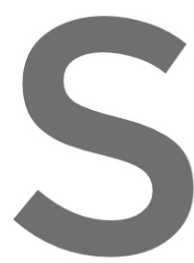

building could have structure its historic chan

The case described

erroneous solutions,

important to provide te
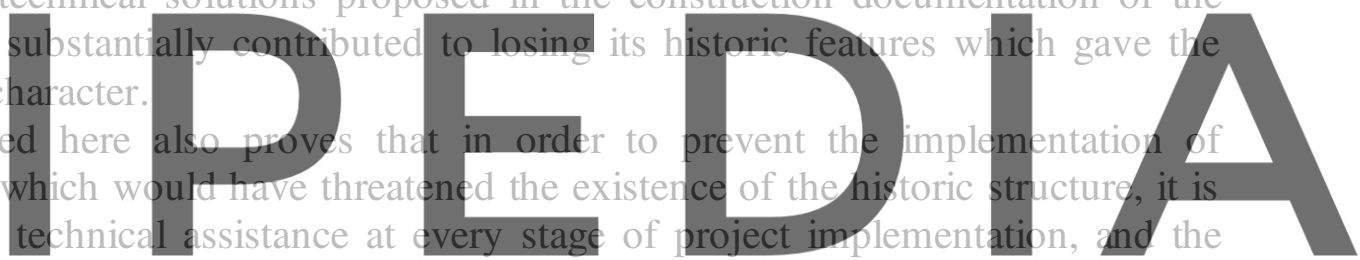

assistance must be provided by those with relevant knowledge and experience.

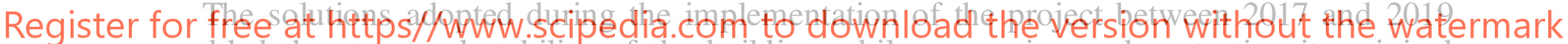
enabled the structural stability of the building while preserving and protecting its original elements, contributing, at the same time, to its historic and scientific value which, in this case, is of an outstanding significance as compared to other such objects in Poland.

Apart from its technical aspects, the case of the Salt House has contributed to changing the way the Historic Preservation Officers have perceived particular elements of the building, such as roof tiles, battens or even mortar used for sealing specific roofing components, which have until now been treated as lacking their historical importance.

\section{REFERENCES}

[1] Ałykow K. and Napiórkowska-Ałykow M., Between Conservators Theory And Modern Construction's Codes. Renovation Of Roof Of 16th Century Salt House In Lubań, Lower Silesia, Poland, In: Branco J.M., Poletti E. and Sousa H.S., (Eds) SHATIS'19 - Structural Health Assessment of Timber Structures, Guimarăes (2019), pp. 119-128

[2] Fokt K., Tekiela Ł., Bena W. and Koreś D., Vademecum of the history of Upper Lusatia. http://www.luzyce-wid.pl/?page_id=237 (2019)

[3] Ważny T., Ufnalski K., Dendrochronological analysis of the Salt House in Lubań (Lower Silesia Province) (2018) 
[4] Krzywka Ł., Historical and architectural analysis and conservation proposals for the Salt House in Lubań (2017)

[5] Ałykow K., Napiórkowska-Ałykow M., 2008. "The renovation of historic buildings problems and hazards of the investment process", Renovations and Monuments 4(28)/2008, 20-23

[6] Gąsior M., A program of conservation and restoration works for the building of the Salt House in Lubań (2018)

[7] Ałykow K. and Napiórkowska-Ałykow M., On the inadequate modeling of the structure of architectural heritage. Journal of Heritage Conservation (2015) 41/2015, pp. 59-64

[8] Murzyn-Kupisz M., 2016. "Values of cultural heritage In the context of socioecomomics". In Heritage value assessment systems - the problems and the state of research. Edited by B. Szmygin. Warszawa, 147-164
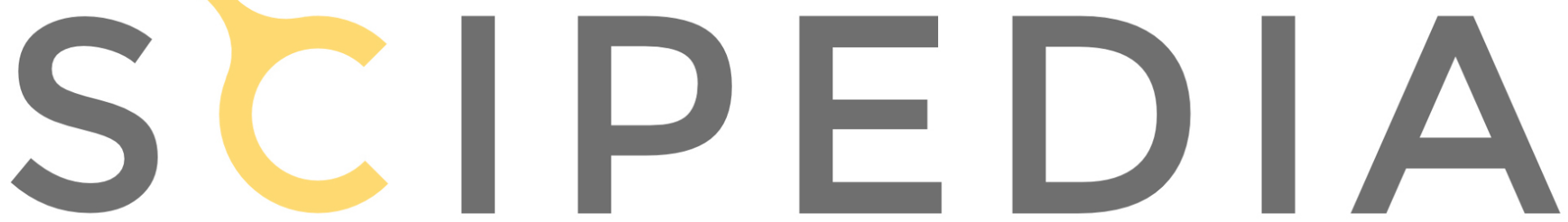

Register for free at https//www.scipedia.com to download the version without the watermark 